\title{
Knowledge Creation and Innovative Behavior in Industry 4.0
}

\author{
Y. Setiawan *, T. Yuniarsih \\ Universitas Pendidikan Indonesia \\ Bandung, Indonesia \\ *yanasetiawan@upi.edu
}

\begin{abstract}
The lack of innovative employee behavior that is described by the phenomenon of decreasing and increasing performance of PT Perkebunan Nusantara VIII is a problem in company organization. If this problem is not addressed immediately, it will have an impact on the achievement of corporate management objectives, which in turn will affect the performance, productivity, and sustainability of the company. The purpose of research is to analyze about (1) knowledge creation and innovative behavior of employees of PT. Perkebunan Nusantara VIII (2) the influence of knowledge creation on innovative behavior of employees of PT. Perkebunan Nusantara VIII. Respondents in this study are employees of PT. Perkebunan Nusantara VIII. The population in this research is employees of PT Perkebunan Nusantara VIII which amounts to 16.815 people, with the minimum sample size amounted to 364 people.
\end{abstract}

\section{Keywords-Knowledge Creation; Innovative Behavior}

\section{INTRODUCTION}

Total production of plantations in Indonesia especially managed by PT. Perkebunan Nusantara VIII has decreased and increased from 2014 until 2016. The production amount of PT. Perkebunan Nusantara VIII consists of tea, rubber, palm, quinine and fruits have decreased and increased from 2014 to 2016. The highest amount of production is achieved by palm oil products, while the lowest number is achieved by quinine products.

In addition to the decrease and increase in the production of PT. Perkebunan Nusantara VIII from 2014 to 2016, the same thing also happened decrease and increase in the amount of product sales of PT. Perkebunan Nusantara VIII from 2014 to 2016.

The number of product sales PT. Perkebunan Nusantara VIII consists of tea, rubber, palm oil, quinine and fruits have decreased and increased from 2014 to 2016. The highest amount of sales is achieved by palm oil products, while the lowest number is achieved by quinine products.

One of the factors causing the decrease and increase of production and sales of PT. Perkebunan Nusantara VIII from 2014 to 2016 is one of the problems of human resources (HR). Symptoms of the problem can be seen from the accomplishment of achievement targets of employee performance.
Based on a study conducted by [1] explains that the process of innovation involves more than just the creation of knowledge, this is a fundamental aspect of innovation. It further explains that in the first stage of knowledge management, knowledge creation or knowledge creation, it is the most influential and most widely referenced theory in the domain of knowledge management.

In the perspective of knowledge creation in the process of knowledge management, According to [2] explains that knowledge creation is a technique, way, or approach to create, disseminate information and knowledge by humans in this individual to create value for the organization. Further [3] explains that this knowledge creation as a model of knowledge creation begins with socialization and moves through four modes of knowledge conversion, forming a spiral. Knowledge Creation moves through four modes of conversion namely socialization, externalization, combination and internalization.

Based on a study developed by [4] it is mentioned that the innovative behavior dimension is divided into five expertise of invention capability by innovators who successfully created innovative products and services for the business world that are associating, questioning, observing, networking, experimenting.

Based on the description of the above issues, it is highly relevant and important to conduct further research on Knowledge Creation and Innovative Behavior in the Industry 4.0.

\section{METHOD}

This study analyzes the effect of knowledge creation on innovative behavior. Research subjects are employees of PT Perkebunan Nusantara VIII. The unit of analysis in this study is the individual i.e. the employees involved in administration activities at PT. Perkebunan Nusantara VIII. Population in this research is employees of PT. Perkebunan Nusantara VIII employees in administrative positions outside the pickers/tappers/harvesters, drivers, maintenance, security units and factory sections of 3999 people. The sample in this study amounted to 363.6 rounded to 364 people. Technique of research data analysis using structural equation modeling. Hypothesis in this research that Knowledge Creation have an effect on Innovative Behavior. 


\section{RESULTS AND DISCUSSION}

Knowledge creation consists of 4 indicators namely socialization, externalization, combination and internalization. Description of the effectiveness score of the effectiveness of the creation is presented in the following figure.

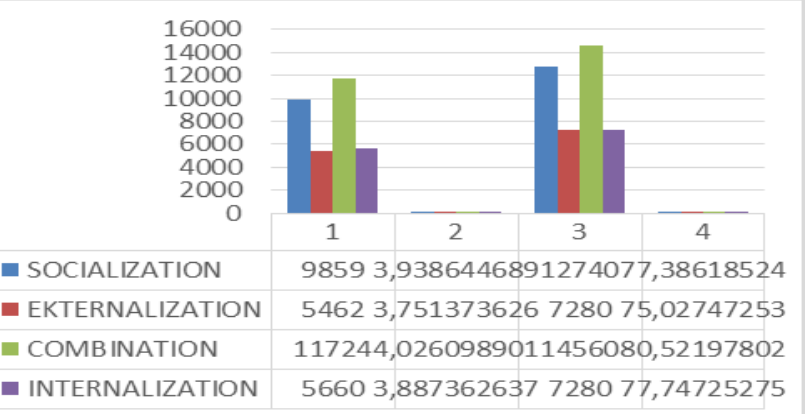

Source : Data Processing Results in 2018

Figure 1. Knowledge creation.

Based on the image above, the combination indicator gets the highest score that is equal to 11.492 or $80.52 \%$ compared to the ideal score of 14,560 for 8 statements that are in the agreed area. Internalization indicators get the lowest score of 5,660 or $77.75 \%$ compared to the ideal score of 7,280 for 8 statements located on the agreed area. This shows that the main factor in the combination is very important to do. As expressed by [5] that turning ideas into new forms of explicit knowledge requires a combination of existing knowledge and ideas. In addition, according to [6] explained that knowledge sharing and innovative spirit are an important part of the internalization process.

The effectiveness of the knowledge creation gained a score of 32.705 or $78.13 \%$, in accordance with the research data included in the effective category. The value describes most employees that knowledge creation is one important factor of an organization. As revealed by [7] that knowledge is a key element whereby firms can stand in a competitive position, and the means by which they can continue to broaden their vision and achieve the goals set by the company.

Innovative Behavior Level consists of 4 indicators that ask questions, make observations, build networks and experiment. Description of the variable score of innovative behavior levels is presented in the following figure.

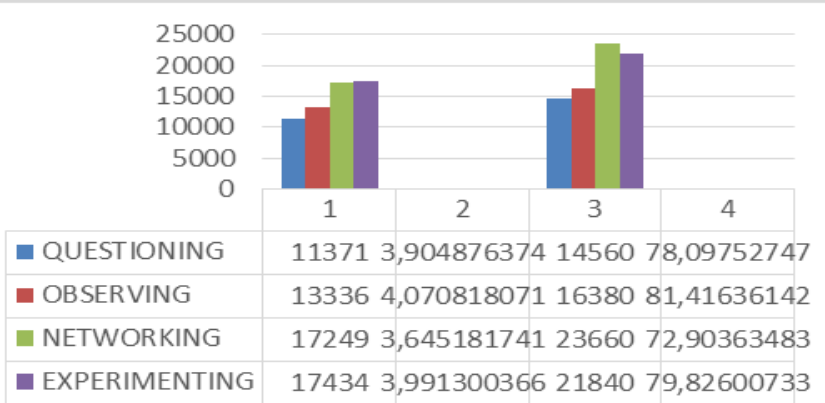

Source : Data Processing Results in 2018

Figure 2. Innovatif behaviour.
Based on the picture above, the experimental indicator get the highest score that is equal to 17,434 or $79,83 \%$ than ideal score 21,840 for 42 statement residing in area agree. Indicators ask questions in innovative behavior level variables get the lowest score of 11.371 or $79.10 \%$ compared to the ideal score of 14.560 for 42 statements residing in the agreed area. This shows that experimenting can trigger ideas of innovation within the company. [4] that experimenting can trigger new ideas to make things work better.

Level of innovative behavior get score of 59,390 or $77,69 \%$ according to research data included in high category. The value represents most employees who claim that employees have innovative behavior in the company's operational activities. In accordance with [8] that innovation not only allows organizations to improve processes and outcomes but also helps employees to master non-routine situations and tasks at work.

The fit test is performed to check the level of compatibility between the data and the model, validity and reliability of the measurement model, and the significance of the coefficients of the structural model. The matching test is performed through several stages: the overall fit of the model, the suitability of the measurement model and the suitability of the structural model. Based on the results of data processing using AMOS 24 obtained results for testing the model as follows.

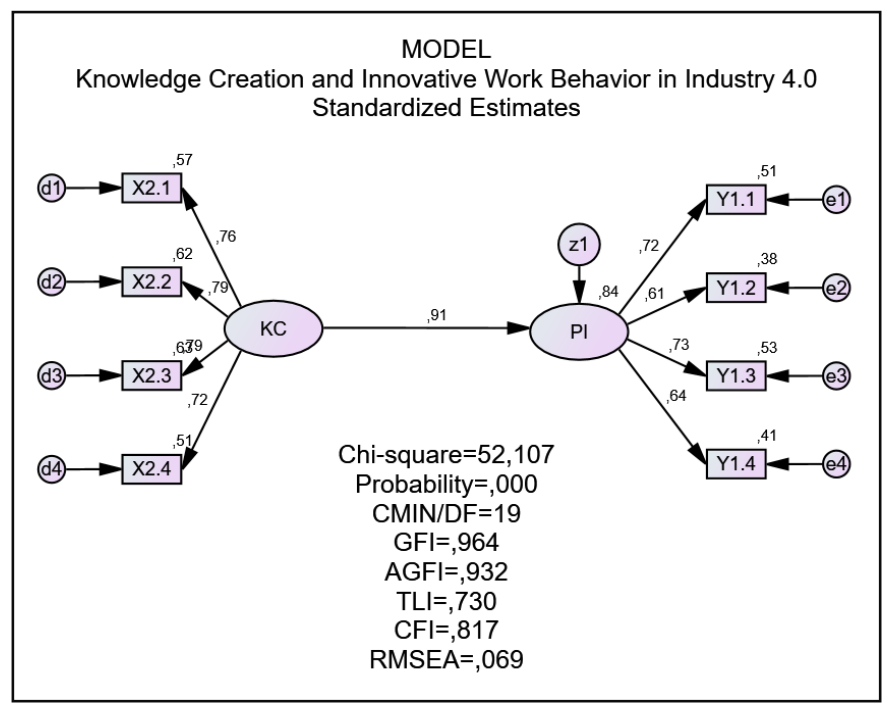

Source : Data Processing Results in 2018

Figure 3. Structural equation modelling.

The general evaluation of the degree of fitness or Goodness of Fit (GOF) are as follows. 
Knowledge creation (KC) has an effect on innovative behavior (PI) of 0.914 or $91.4 \%$. The value of the path coefficient $(\mathrm{SRW})>0$. This shows that the influence of knowledge creation on innovative behavior get positive and significant results. Based on these data show the high level of innovative behavior influenced by knowledge creation. This is in line with the opinion expressed by [7] that knowledge can be made, shared, enhanced, and justified through collaborative social processes and individual cognitive processes such as reflection.

Adjusted GFI (AGFI)
Root-Mean-Square Error

of $\quad$ Approximation $0,069 \quad$ Good Fit

(RMSEA)

Tucker-Lewis Index (TLI) $\quad 0,730 \quad$ Marginal fit

Normed Fit Index (NFI) $\quad 0,750 \quad$ Marginal fit

Comprative Fit Index CFI $\quad 0,817 \quad$ Marginal fit

Source : Data Processing Results in 2018

The suitability test of the above model yields $\mathrm{df}=19$ with a chi-square value of 52.107, and a probability (p-value) value of $0.000<0.05$ indicates a close fit model. Goodness-offit (GFI) value $0.964 \geq 0.90$ indicates a good fit model. Adjusted GFI value (AGFI) $0.932 \geq 0.90$ indicates a good fit model. Root-Mean-Square Value Error of Approximation (RMSEA) $0.069 \leq 0.08$ indicates a good fit model. The value of Tucker-Lewis Index (TLI) $0.630 \geq 0.90$ indicates a marginal fit model. Normal Fit Index (NFI) value $0.750 \geq 0.90$ indicates a marginal fit model. The value of Comprative Fit Index CFI $0.817 \geq 0.90$ indicates a marginal fit model.

This is in keeping with Alipour et al. (2011) that the creation and transfer of knowledge, understanding the concept of knowledge is essential because employees sometimes fail to gain new knowledge because of their misconceptions of the real concept. Further [7] reveals that Knowledge is the whole body of cognition and skills that individuals use to solve problems. In addition [5] explains that every member of the organization creates knowledge; thus, the individual is the driver of knowledge creation.

Table 2. Parameter estimation results model knowledge creation and innovative behavior.

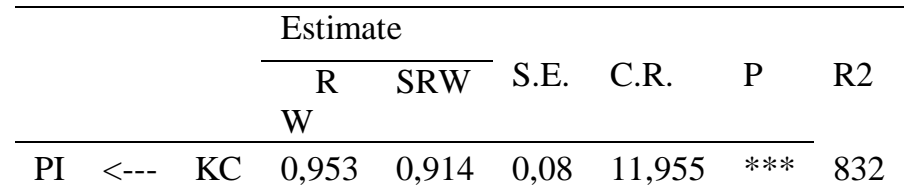

The results of significance test on the path coefficient estimation on the model are all significant at the 5\% error rate or the P-value value of each path coefficient having a value $<0.05$. Based on the above description it can be said that the model is the best-fit model in explaining the phenomenon of knowledge creation (KC) and innovative behavior (PI). Therefore the model will be used as an empirical foothold to answer the proposed research problem.

\section{The effectiveness of Knowledge Creation}

Individuals in the organization must have competence through knowledge and skills to carry out organizational activities. This is in line with the opinion of [9] which explains that the individual must have knowledge of what to do and how to do it. Further explains that each individual must have the knowledge and skills to change the behavior of individual performance. When the Individual has knowledge and skills in the operational activities of the organization it will have an impact on the achievement of the performance and success of the organization. This is in line with the opinion of [7] that in order to maintain a competitive advantage, the manager's understanding of the creation and transfer of knowledge is essential because the success of the firm can be determined by the manager's intellectual capital.

Each individual must have the ability to develop knowledge in the organization. According to [5] Creation of model knowledge is developed based on the tacit and explicit knowledge transformation within an organization. Tacit knowledge is deeply rooted in the actions, ideas, and values of individuals, therefore very personal, difficult to formulate and difficult to communicate with others. Explicit knowledge can be expressed in words or numbers and shared in documents, manuals, specifications, or data.

Knowledge Creation consists of five indicators: Socialization, Externalization, Combination, Internalization. Socialization contributed 0.757 . Socialization is the first stage in the knowledge creation modes of conversion. According to [7] to create new knowledge in the organization and acquire the required knowledge from the outside. Learning organizations thrive with quality knowledge and communication. Knowledge must therefore be accessible whether received from people or through information technology.

Meanwhile, according to [10] that the sharing of individual experiences primarily take steps through face-to-face interaction. This represents the stage of socialization. According to [11] that socialization is a process of changing the knowledge of individual tacit into tacit knowledge of the group. Furthermore [6] that socialization is a process of tacit knowledge change into explicit knowledge. This process supports concentrated work and task-oriented work processes, which are task-oriented, and the focus is on real performance. The meeting room is an example of a structural place.

Externalization contributed 0.786. Socialization is the second stage in the knowledge creation modes of conversion. 
According to [10] that the step of externalization in the creation of knowledge, is the space in which knowledge is secretly made explicit and divided through the process of dialogue and collaboration between individuals The Combination contribution of 0.794 . Combination is the third stage in the knowledge creation modes of conversion. According to [10] that a combination of existing and new explicit knowledge, since explicit knowledge is relatively formalized and easily transmitted to a large segment of the population.

Internalization contributed 0.715 . Internalization is the fourth stage in the knowledge creation modes of conversion. According to [10], that context for active and sustainable individual learning and in accordance with the internalization step. Then [7] explains that to create new knowledge in the organization and acquire the required knowledge from the outside. Learning organizations thrive with quality knowledge and communication. Knowledge must therefore be accessible whether received from people or through information technology.

\section{The Effectiveness of Innovative Behavior}

Innovative behavior is a capability and a character that must be owned for every individual in a business organization. This is true with getting [4] that in the world of business innovation, almost everyone has the capacity to think creatively and innovatively. It further explains that creative and innovative ideas are not just cognitive skills, but also from behavioral skills. Innovative Behavior consists of five indicators: ask questions, make observations, build networks, conduct experiments Ask questions contribute of 0.717 . Asking questions is an important part of innovative behavior in the first stage. According to [4] ask questions of inquiry and ask questions that evoke new understanding, creative understanding within the organization.

Observations, contributed 0.613. According to [4], making observations is an important part of innovative behavior in the second stage. Observing observes the internal and external environments of the organization to acquire and ideas about new ways to do things in the organization, solve problems, and generate new business ideas.

Building a network, contributing 0.731. Building a network is an important part of innovative behavior in the third stage. According to [4], networking is to find and test ideas through various networks of individuals with different backgrounds and perspectives. Innovators in this perspective not only do social networking, or resource networks, but also actively seek new ideas and discuss with individuals who have new insights about business ideas. Meanwhile, according to [12] that for individuals, high levels of innovative levels of behavior within teams improve the performance of their workplaces because they benefit from the collective dynamics created by other team members who are also involved in innovative behavior.

Experiment, contribute 0.641. Conducting an experiment is an important part of innovative behavior in the third stage. According to [4], explaining that experimenting is by trying new experiences, driving new ideas, and piloting new experiments.

\section{The Effect of Knowledge Creation on Innovative Behavior}

The test results of the influence of knowledge creation (KC) on innovative behavior (PI) are shown by analyzing regression weights analysis of structural equation modeling where $\mathrm{CR}$ and $\mathrm{P}$-value of the data, if it compared to the required statistical constraints, are for values $\mathrm{CR}>1.978$ and for $\mathrm{P}$-value $<0.05$. The influence of knowledge creation $(\mathrm{KC})$ on innovative behavior (PI) has standardized estimate (regression weight) of 1,184 with CR value of 45,127>1,978 and $\mathrm{P} 0,001 \leq 0.05$.

This shows that the influence of knowledge creation on innovative behavior get positive result. Based on these data show the high level of innovative behavior influenced by knowledge creation. This is in line with the results of [7] study which explains that creating, obtaining and transferring knowledge and modifying its behavior to reflect new knowledge and insights. Furthermore [7] explains that knowledge was first made by individuals, after which through the process was transformed into organizational knowledge.

In addition to the creation and transfer of knowledge, a manager must design structures, in which organizational members can share their information and experiences, enhance and synthesize their knowledge, as well as evaluate their ideas. Appropriate structures can support problem solving, critical thinking and innovation that are critical to the creation and transfer of knowledge.

The study results of [5] revealed that the knowledge creation system will improve learning, increase the accumulation of knowledge, and improve the quality and quantity of each innovation in the company. The knowledge creation system has become one of the important organizational issues. It is considered important to improve innovation, reduce costs, and improve product quality. Based on that opinion that the system can encourage and facilitate learning in individuals, through a spiral process of knowledge creation that involves the continuous and dynamic conversion between tacit and explicit knowledge at the individual, group, organizational and interorganizational levels. This research shows that in addition to this knowledge creation appear on the improvement of innovative behavior of individuals, also have an impact on the improvement of organization performance.

The result of $[10\}$ study explains that the creation of knowledge as a spiral interaction process associated with the integration of explicit knowledge and tacit knowledge so as to enhance the competitiveness of the organization in innovation. [13] explains that the process of knowledge creation is an important aspect of corporate knowledge management initiatives operating in a changing environment that depends on innovation to compete. Results of research [14] stated that knowledge assets contribute to improving the innovative capacity of an organization. 
[5] Anggraeni, E., Machfud, Maarif, M. S., \& Hartrisari. (2017). Contextual-based knowledge creation for agroindustrial innovation. Gadjah Mada International Journal of Business, 19(2), 97-122. https://doi.org/10.22146/gamaijb.23287

Knowledge creation is an effective category with factors that give dominant contribution is a combination factor. Innovative behavior including high category with factors that give dominant contribution is the factor of experiment. Employee performance is very high category with the factor that gives dominant contribution is the supporting factor toward the achievement goal of organization. Knowledge creation influences and enhances employee's innovative behavior in industry 4.0. The knowledge creation indicator that gives the highest contribution is the externalization indicator.

PTPN VIII is expected to increase the effectiveness of knowledge creation through externalization factor that is translating tacit knowledge into the concept of explicit knowledge through dialogue and reflection process.

\section{REFERENCES}

[1] Hislop, D. (2009). Knowledge Management in Organization (Second Edition). New York: Oxpord Universty Press.

[2] Takeuchi, H., \& Nonaka, I. (2004). Hitotsubshi on Knowledge Management. Singapore: John Willey \& Sons (Asia).

[3] Nonaka, Ikujiro. 2004. Knowledge Creation and Dialectics. Hitosubashi on Knowledge Management. Hirotaka Takeuchi dan Ikujiro Nonaka. Singapore: John Wiley \& Sons (Asia), hlm. 29-46.

[4] Dyer, J., Gregersen, H., \& Christensen, M. (2011). DNA Inovator. Menguasai Lima Keahlian Para Inovator Destruptif. Yogyakarta: Andi Offset.

[6] Peltoniemi, S., \& Poutanen, J. (2017). Spatial solutions supporting information exchange and

[7] Alipour, F., Idris, K., \& Karimi, R. (2011). Knowledge Creation and Transfer: Role of Learning Organization. International Journal of Business Administration, 2(3), 61-67. https://doi.org/10.5430/ijba.v2n3p61

[8] Messmann, G., \& Mulder, R. H. (2015). Reflection as a facilitator of teachers' innovative work behaviour. International Journal of Training and Development, 19(2), 125-137. https://doi.org/10.1111/ijtd.12052

[9] Wibowo. (2017). Manajemen Kinerja (Kelima). Depok: Rajawali Press.

[10] Hsiao, J. (2017). Knowledge Creation and Virtual Knowledge ba: A Case Study of Car Dealer in Taiwan. American Journal of Applied Sciences, 14(10). https://doi.org/10.3844/ajassp.2017.974.982

[11] Nenonen S., and Storbacka J. (2010). Business model design: conceptualizing networked value co-creation. Tersedia di https://pdfs.semanticscholar.org

[12] Hughes, M., Rigtering, J. P. C., Covin, J. G., Bouncken, R. B., \& Kraus, S. (2018). Innovative behaviour, trust and perceived workplace performance. British Journal of Management, 0, 1-19. https://doi.org/10.1111/1467-8551.12305

[13] Sołek-Borowska, C., Exploring entrepreneurial spirit of students at Warsaw School of Economics in Warsaw. Horyzonty Wychowania, 15 (33), 119-129. DOI: 10.17399/HW.2016.153308

[14] Nguyen, T. V., Phan, A. T. T., \& Nguyen, M. T. T. (2016). Knowledge Creation, Innovation and Financial Performance of Firms: Evidence from Vietnam. International Journal of Business and Management, 11(6), 95. https://doi.org/10.5539/ijbm.v11n6p95 